the assistance of C. E. von Baer and H. Rathke, and in the second edition, I835, with the same assistance, and, besides them, with E. Meyer and J. Valentin, and in a French translation of the same work, $\$ 237$ gives an account of Sprengel's discoveries. "If he should have gone a little too far in some cases it would be without importance; the same occurs with every scientist who makes a great discovery, and becomes with it enthusiastically excited." I know personally that Burdach's well-reputed assistants were thoroughly acquainted with Sprengel's observations.

Prof. H. Burmeister had studied in Greifswald and in Halle, and published his "Handbuch der Entomologie," I832; an English translation by F. Shuckard. He speaks (vol. i. p. 303) about Sprengel's and Koelreuter's observations at some length, also as well known and of the highest importance. Prof. Burmeister will be indeed best able to state if he became acquainted with the facts in Prof. Hornschuck's lecture on the physiology of the plants, "naturæ mysterias nobis aperire expertus est" ("vita" in Prof. Burmeister's dissertation), or in Halle by Prof. Carl Sprengel, the nephew of Rector Sprengel, or somewhere else. know personally that in Berlin, Link, Lichtenstein, Klug, Erichson were entirely acquainted with Sprengel's discoveries. Prof. Kunth was a very old friend of Heim (Life, ii. p. 9), and beyond doubt acquainted with the facts, though he has not brought it forward in his lectures after Dr. F. Müller's statement. I was assured by scientific friends that Treviranus in Bonn and Nees von Esenbeck in Breslau were well acquainted with Sprengel. I confess that I am entirely at a loss to understand how it happened that Sprengel was unknown to scientists in England, where Kirby and Spence's "Introduction," \&c. had seven editions from I8I5 to I867, the last of I3,000 copies. There would be no difficulty to find in German libraries mor publications to corroborate my views, but I believe those quoted are sufficient to prove what I intended to state in my former note.

Cambridge, Mass., March 24

H. A. HAGEN

\section{Salt-water Fish-Types in Fresh Water}

Mr. HARDMAN's observations on the occurrence of "sea-fish in fresh-water rivers" (NATURE, vol. xxix. pp. 452-53) are not by any means unique, as he has supposed. On the contrary, cases similar to those he has recorded are so frequent as to justify him in believing that "some caution must be observed in the classification of strata as fresh-water or marine on the evidence of fish alone." The incursion and confincnient of the two types specially mentioned-the "sunfish" and "shark"-in fresh water have many parallels. For instance, in NATURE, vol. xiii. p. I07, Messrs. W. W. Wood and A. B. Meyer have recorded that "near Manila is the Lacuna de Baij, a large sheet of water" whose "water is quite fresh, and, after settling, perfectly potable," but in which live a sunfish (Pristis perotellii) and a small shark. Further, in Lake Nicaragua, whose mean height above mean tide in the Pacific and Atlantic Oceans is 107.63 feet, are likewise found a sunfish-apparently Pristis antiquorum - and a peculiar shark-Eulamia (or Carcharias) nicaragutnsis. The last have been especially noticed in a "Synopsis of the Fishes of Lake Nicaragua, by Theodore Gill, M.D., and J. F. Bransford, M.D., U.S.N.," in 1877 (Pros. Acad. Nat. Sci. Phila., pp. 175-91). Therein it is also urged that "these instances, supplemented as they are by many others, are sufficient to convey a caution against too extensive generalisation of the physiographical conditions hinted at by fossil remains of aquatic types.

Washington, April I

\section{"The Axioms of Geometry"}

Mr. RoBt. B. HAXward has written to me that some of the statements in my article, "The Axioms of Geometry," in NATURE, March 13 (p. 453), are too sweeping, and that in particular Euclid I. I6 does not necessarily hold for the geometry of the eye-being, or, to use the more familiar language of spherical geometry, that this theorem does not hold unless the median line of the triangle on the side on which the exterior angle lies is less than a quadrant.

$\mathrm{Mr}$. Hayward has also pointed out that the error lies in the assumption that a terminated straight line "may be produced to any length."

All this is clear enough, and I was conscious of it when I wrote the article. In fact I meant to add, but somehow omitted to do so, that every figure considered has to be limited to less than a hemisphere, or to less than half the space round the eyebeing. If this is done, and if by the whole figure is understood the given figure together with any addition required for the proof, then my statements will hold, but with one exception. $\mathrm{I}$ was wrong in saying that Legendre's proof, given by $\mathrm{Mr}$. Casey, can be treated in the same manner as Sir Wm. Hamilton's For in this proof a series of triangles is constructed with sides which increase till they become infinite. The reasoning is therefore not applicable to the sphere. But neither is it to the plane. We have no right to reason about infinite figures as we do about finite ones.

O. HENRICI

\section{Wild Duck laying in Rook's Nest}

A WFEK ago to-day six wild duck's eggs were taken out of a rook's nest about four miles from here. The rookery is situated on the banks of the River Test. The nest from which these egg. were taken (the bird flew off as the nest was approached) was in a horse-chestnut tree, and was about thirty feet from the ground the tree was about twenty-five yards from the river, and was surrounded by others, mostly elm. An instance of so unusual a situation for wild duck's eggs might, I thought, interest some of your readers. JOHN H. WILLMORE

Queenwood College, near Stockbridge, Hants, A pril 3

[Our correspondent has sent us one of the eggs referred to, which we have submitted to a well-known oologist, who is of opinion that the egg is most likely a wild duck's.--ED.]

\section{The Remarkable Sunsets}

I LEARN from Mr. Frank Atwater, a teacher in the Native College here, that he observed the "glow" at $5 \mathrm{a} . \mathrm{m}$. on September 5 , when landing from the steamer at Maalaea, thirteen miles south-east of this. He had arrived in the islands only two days before, and marvelled much if such were the sunrises here. He is the only person I have met who observed it prior to the evening of that day. Mr. Atwater's date is verifiable by the regular movements of the steam-packet.

Lahaina, Hawaiian Islands, March I4

S. E. BISHOP

\section{Cats on the District Railway}

With reference to Mr. Vicar's letter last week (p. 55I) abou the cats at Victoria Station, I beg to state that there are cats all over the District Railway both in and out of the tunnels, and many of them-familiarly called "Stumpy" by the men on the line-can testify by the shortness of their tails to the hairbreadth escapes they have had from passing trains. Those I have seen are mostly full-grown cats, and only once have I seen a kitten walking on the rails, and that was at night after the traffic had ceased. At one signal-box which is built on a platform over the line, and the only access to which is by a steep iron ladder, down which no cat could climb, there are two full-grown tabbies -toms I believe-and I have often seen them asleep behind the signal bells or even on the handrail of the platform, utterly callous to the trains rushing by underneath. As a rule the men are very kind to them, and give them milk, \&c.

I would add that until quite recently there was a small fountain and circular basin near one of the pumping-engine houses wherein were two fish which had been there for about twelve years. One died last year, and now I see the basin has been converted into a flower-bed by the man in charge.

Victoria Station, District Railway, April I4

\section{THE GEODETIC SURVEY OF THE UNITED} STATES

WE would congratulate Prof. J. E. Hilgard, the Superintendent of the Survey, on his first general Report on the work of his department, which gives an account of the Survey for the fiscal year ending June I 882. We are unable to gather why its issue has been deferred until now, but its arrival at the present time is not the less opportune, particularly as the programme of I " Report of the Superintendent of the Survey," Washington, 1883 , $55^{6} \mathrm{pp},{ }^{\mathrm{t}} \mathrm{to}$. 
the approaching International Geodetic Conference at Washington is beginning to claim decision.

The Report describes the nature and general procedure of the coast and topographical surveys, with a description of the instruments employed; full details of the observations and their methods of reduction being given.

Whilst the original leading aim of the Survey, the security of navigation, has been kept in view, other objects incidental to the work of trigonometrical survey, and of the highest scientific interest, have not been lost sight of.

Hydrographic surveys have been prosecuted in the waters and off the coasts of seventeen States and Territories, and topographic surveys for the exact definition and delineation of shore line have been carried on in eleven States and Territories. The triangulations for this work have been advanced in twenty-two States and Territories, and included the measurement of the base-line in California; and also, as is well known, the extension of the trans-continental triangulations urged by the late Prof. Peirce, for connecting the surveys of the Atlantic and Pacific coas.s. In the interior States the work has included the continuation of the triangulations of Kentucky, Tennessee, and other States.

The incidental work has comprised the carrying of lines of precise "leveling" between points far distant (i 125 miles); the exchange by telegraphic signal of the longitudes of important cities; the usual observations for latitude and azimuth, and of the magnetic elements; the determination of the force of gravity by pendulum experiment; and the study of ocean currents, particularly of the Gulf Stream.

For the year ending June 1884 the cost for carrying on the work of the U.S. Coast and Geodetic Survey, by which designation this department has been known since 1878 , was estimated at $\$ 573,000$, and it is gratifying to note that on the other side of the Atlantic the value of active scientific inquiry continues to be recognised by the State, provision having been made for further tidal, magnetic, gravity, and other scientific observations.

In a geodetic survey extending over an area so large as that of the United States the question of the size and figure of the earth becomes of great importance. Although, as Prof. Hilgard points out, different opinions are held as to the mode of prosecuting gravity experiments, all geodists agree that widely-distributed pendulum observations will give results valuable to geodesy and sreology. It is undoubtedly desirable that opportunity should not be lost of combining the results of pendulum observations taken in different parts of the globe, and we trust that the valuable pendulum work done in India ("Great Trigonometrical Survey," vol. v.), and the discussion at the informal conference on gravity determinations between Col. J. Herschel, R.E., Prof. S. Newcomb, and the officers of the Survey Department, which was held at Washington in May I882, may stimulate the recognition in this country of the necessity of further experiment and inquiry in this direction. Although the conclusions proposed by Prof. Newcomb, as amended and adopted by the conference, have been elsewhere discussed, it appears desirable at the present time again to invite attention to them. Generally they are as follows :-

r. The main object of pendulum research is the determination of the figure of the earth.

2. A complete geodetic survey should include determinations of the intensity of gravity.

3. A minute gravimetric survey of some limited region is at present of such interest as to justify its execution.

4. Extended gravimetric linear exploration is desirable.

5. Each series of such determinations should be made with the same apparatus.

6. Such determinations ought commonly to be accurate to the $r / 200,000$ th part.
7. All pendulums should be compared at some central station.

8. Determinations of absolute gravity will probably prove useful in comparing the yard and the metre, and they should at any rate be made in order to test the constancy of gravity against the constancy of length of a metallic bar.

9. In the present state of our experience, unchanged pendulums are decidedly to be preferred for ordiniry explorations.

In an appendix (No. 2I) is given the reduction, with the employment of modern constants, made by the late Dr. C. R. Powalky at the charge of the Bache Fund of the National Academy of Sciences, of the places of I 50 stars observed by La Caille at the Cape of Good Hope and at Paris, between 1749 and 1757 . Since all these stars have been re-observed in recent years at Melbourne and at the Cape, the comparisons of La Caille's places with these determinations and with those of Dr. B. A. Gould at Cordoba became of scientific value.

An account is also given of the measurement of the primary base-line in Yolo county, Sacramento Valley, begun in 1879 with the new compensating base apparatus designed by Assistant C. A. Schott. The measurement was made under the directions of Assistant George Davidson, but the discussion of its results does not appear in the present Report

The measuring bar of the compensating apparatus is of a construction different from other compensating bars, but involves no new mechanical principle. It is composed of two metals, zinc and steel, so proportioned as to be compensatory for change of temperature, the expansion or contraction of a zinc bar five metres in length being counteracted by the expansion or contraction of the two steel bars between which it is placed.

The determination of the rate of expansion of the subsidiary steel and zinc bars by which the five-metre standard was verified was done by means of two micrometer microscropes securely fixed to stone piers placed a metre apart, the metre bar whose rate of expansion was to be determined being compared when at different temperatures with the distance between the two microscopes as determined at a constant temperature by reference to a second standard metre bar. The distance between the microscopes thus becomes a function of the temperature, and in this respect we cannot but think that the method attributed to General Wrede, by which the variable distance between the microscopes becomes unimportant, has a decided advantage.

The active investigations since $187 \mathrm{I}$ as to the distribution of terrestrial magnetism in North America have beome generally known from the reports of Prof. Hilgard, as well as by the publication of Mr. Schott's paper on the magnetic variation of secular declination. $\mathrm{Mr}$. Schott also now gives an important appendix to the Report on the distribution of the magnetic declination in the United States at the epoch January I885, together with three isogonic charts in continuation of those issued by the Survey up to the year 1876 . The results are also given of the magnetic observations made by Lieut. Very on the north-eastern coast of America, particularly at Labrador, in the remote settlement of Nain (lat. $=56^{\circ} 33^{\prime} \mathrm{N}$., long. $6 \mathrm{I}^{\prime} 44^{\prime} \mathrm{W}$.).

In the exploration of the Gulf Stream, the facts brought out by the deep-sea soundings of Commander J. R. Bartlett during $188 \mathrm{r}$, with Siemens's admirable electrical deep-sea thermometer, are also referred to; and the account of the deep-sea soundings taken off the Atlantic coast between 1879 and 1883 by Lieut. J. E. Pillsbury, in connection with the exploration of the Culf Stream, and the discussion by Prof. Ferrel on the tides of the Pacific coast are now published. The inquiries of Dr. Thos. Craig as to fluid motion, particularly as to the motion of 
vessels and of bodies such as pendulums, when totally immersed in fluid, are also adverted to.

Twenty-five useful maps and charts are attached showing the general progress of the survey, particularly on the coasts of Florida, California, Oregon, and Carolina; together with illustrations of the apparatus used. As compared for instance with the precise drawings given by General Ibanez in his Reports in 1860 and $186_{5}$ on the Madrid base-line, there may perhaps be room for improvement in the finish of the illustrations given in this Report.

In the Report of the Superintendent for I 883 we shall look forward with interest to the results of the experimental researches on the force of gravity, by Assistant C. S. Peirce, who is now visiting Europe for the purpose of his inquiries.

In the success with which the Superintendent has been able to deal with the different brancbes of his department, much is due, as he indicates, to the forethought and systematic treatment of his eminent predecessors, particularly to Cariile P. Patterson, to whose memory a graceful tribute is rendered in the Report; as well as to the able assistance which the Government have placed at the Superintendent's disposal.

\section{AGRICULTURE IN SUSSEX 1}

$\mathrm{T}^{\mathrm{H}}$ IS Report bears evidence of a considerable amount of careful research bearing upon the agricultural practice of Sussex. The honorary secretary, Major Warden Sergison, must be congratulated upon his zealous administration of the finances, whereby an annual income of about $770 l$. has been secured for the three successive years of active operations. This Report deals with the results of the third year's work, which completed the period over which it was originally calculated that the work should be extended. We are therefore in a position to form some opinion as to the practical value of the results which have been gained. It appears from this Report that it is intended to extend this inquiry.

These experimental researches have been conducted by Mr. Thomas Jamieson, the Fordyce Lecturer on Agriculture in the University of Aberdeen, and it will be interesting to notice the improvements and economies which are claimed in his Report as resulting from this rather costly investigation. He says:-_"The results are too numerous to give, ..." but "an attempt will be made to give in a general way the lessons they seem to teach." $\mathrm{He}$ then proceeds to indicate these, placing them in the form of question and answer. We will take the first of these.

"What food do plants need? Prior to the experiments now recorded, the answer to this question would have been 'Nitrogen, phosphorus, potassium, sulphur, calcium, magnesium, iron.' The results of the experiments warrant us in saying that the latter four substances may be disregarded by farmers. We thus realise the value of experiments. If the farmer of ioo acres will lay his manure bill before a chemist, and ask him to calculate how much he has paid for those useless-or hurtful-ingredients, he will recognise the direct benefit of such experiments."

Those who have watched the good work which $\mathrm{Mr}$. Jamieson has done in connection with the Aberdeenshire Agricultural Association, and who have recognised the opposition with which he had to contend, cannot but regret the hasty conclusion at which he has arrived. It is a very bold assertion to make that sulphur, calcium, magnesium, and iron are not needed as plant-food. He cautions his friends "not to be led away by opposed statements, however plausible, if unaccompanied by proof." In this case Mr. Jamieson shall supply his own proof, for which purpose we refer to the Report of the

1 "The Annual Report of the Proceedings of the Sussex Association for he Improvement of Agriculture in Sussex. Season $188{ }_{3}$."
Aberdeenshire Agricultural Association, 1875-76, p. 29. Here Mr. Jamieson reports a very valuable series of experiments which he made. White sand was supplied with a!l the ingredients found in turnips-except one-and turnip seeds were then sown. He says:- "Precisely the same sand, precisely the same seed, precisely the same watering, precisely the same ingredients added, except onewhich was purposely omitted-calcium. In consequence of this omission, although all the other ingredients were present in abundance, the healthy seed produced healthy young plants, but speedily the whole of them died. Just as in an ordinary chemical experiment the desired substance' cannot be formed if one of the essential ingredients is absent." The lesson derived from this experiment is perfectly consistent with agricultural science, and it is a source of profound surprise to find that this substance-calcium-is one of the four bodies named in the Sussex Report as being unnecessary, and that it should be stated that "farmers will not hurt their crops by omitting these four elements." This is a dangerous lesson to deduce from this valuable series of experiments, and we regard it with the greater regret because the facts do not justify such a conclusion.

Other examples might be selected from this Report, which conflict with other experimental trials conducted with, at least, equal care, which also tend to show the necessity for taking more practical views of the results gained. The opinions expressed upon permanent pasture are also open to severe criticism. If the general series of Sussex experiments be placed in comparison with the investigations carried out for the Aberdeenshire Agricultural Association, they will be found devoid of those great national advantages which must long attach to the Scotch experiments. The value of the Aberdeen Association work has never been as fully appreciated as it deserves, and the agricultural public would have been highly gratified if the Sussex Association experiments had been equally definite and satisfactory.

\section{SOCOTRA}

FOUR years have elapsed since an expedition was sent out from this country by the British Association and the Royal Society to explore the Island of Socotra. With the exception of diplomatic visits by the resident at Aden in the two or three preceding years, and of a short exploration in 1847 by the French.naturalist Boivin, there is no record of any European having sojourned on the island since the date, forty years ago, of its abandonment by the Indian troops which had occupied it for this country during four years, and Wellsted's account of his survey of the island (in Fourn. Roy. Geog. Sor. v. 1835) made in 1834 , has been up till now the most recent and most satisfactory. It is remarkable that an island so long neglected and forgotten should be visited in two successive years by exploring expeditions; yet this has happened. In I 88I a party of German explorers followed the British Expedition. This German Expedition to Socotra formed part of a scheme of scientific exploration of many unknown or but little-known regions of the globe set on foot by Dr. Emil Riebeck, and for which his liberality provided the means, and the results of this portion of his undertaking, some account of which now lies before us, must be gratifying to him as they are valuable to and welcomed by science. Dr. Riebeck was accompanied to Socotra by the well-known traveller Dr. Schweinfurth and two other companions, Drs. Mantay and Rosset-a quartet of observers well qualified to take advantage of every opportunity of extending our knowledge of nature. Many

I “ Ein Besuch auf Socotra mit der Riebeck'schen Expedition." Vortrag von Professor Dr. Schweinfurth. (Freiburg, r 884 .)

"Allgemeine Betractungen über die Flora von Sc cotra," von G. Schweinfurth. Sep. Abd. aus Engler's botrnischen Jahrbiuchern, v. (1883).

furth. Sep. Abd. aus Engler's botanischen Jakrbiüchern, v. (1883). d. deutsch. Malakol. Gesellschaft, No. 10(188I). 